Научная статья

УДК 821.512 .31

DOI 10.18101/2686-7095-2021-2-62-70

\title{
«НЕМЫСЛИМО КОРОТКОЙ ЖИЗНИ ВСПЫШКА»: ОПЫТ ЛИТЕРАТУРНОЙ БИОГРАФИИ НАМЖИЛА НИМБУЕВА
}

\author{
( С Дампилова Людмила Санжибоевна \\ доктор филологических наук, главный научный сотрудник \\ Институт монголоведения, буддологии и тибетологии СО РАН \\ Россия, 670047, Улан-Удэ, ул. Сахьяновой, 6 \\ dampilova_luda@rambler.ru
}

\begin{abstract}
Аннотация. Автор статьи представляет свой вариант литературной биографии бурятского русскоязычного поэта Намжила Нимбуева (1948-1971). Страницы биографии детство, роль отца в становлении личности будущего поэта, начало творчества, учеба в Литературном институте им. А. М. Горького, ранняя смерть - сопровождаются размышлениями о значении поэтического наследия поэта для нескольких поколений читателей. Важными условиями для создания биографии поэта, по мнению автора, представляются истоки творчества, моменты, объясняющие билингвизм расскоязычного национального поэта, материалы эпистолярного характера, а также воспоминания родных и друзей поэта, критические статьи и отклики специалистов. Главным же требованием остается отражение характера, личности, эстетических представлений в творчестве поэта, так рано ушедшего из жизни и оставившего благодарную память в сознании читателей.
\end{abstract}

Ключевые слова: поэт Намжил Нимбуев, поэзия, проза, биография, отражение личности в творчестве

\section{Для цитирования}

Дампилова Л. С. «Немыслимо короткой жизни вспышка»: опыт литературной биографии Намжила Нимбуева // Вестник Бурятского государственного университета. Филология. 2021. Вып. 2. С. 62-70.

Биография Намжила Нимбуева, прожившего 23 года, - это его детские и юношеские годы. А литературная биография поэта Нимжила Нимбуева длится вот уже несколько десятилетий и продолжается в памяти все новых и новых поколений.

С этой фразы мы начали писать литературную биографию бурятского поэта, чтобы ответить на вопрос, почему и сегодня поэзия Намжила Нимбуева живет в сердцах читателей - его современников и представителей подрастающих поколений. И почему его стихи переводят на другие языки, вдохновляют живописцев, скульпторов, актеров и режиссеров, музыкантов, других поэтов. Уникальна эта продолжающаяся любовь к поэту, хотя он ушел из жизни в 1971 г. Первая книжка «Стреноженные молнии» вышла в Улан-Удэ в 1974 г., и это стало началом литературной биографии поэта, началом стремительного пути поэзии Намжила Нимбуева к читателю.

Намжил родился 11 июня 1948 г. в Улан-Удэ, вырос в бурятской семье, сохранившей вековые традиции, понятие рода, уважение к предкам. Связь поколений в национальной традиции - одна из самых крепких связей. Бабушки, дед, 
Л. С. Дампилова. «Немыслимо короткой жизни вспышка»: опыт литературной биографии Намжила Нимбуева

отец, мать, говорившие дома только на родном языке, были истоком его мировосприятия. Позднее он напишет, что город его научил русской речи, значит, эта речь пришла к нему не с материнским молоком, но эту речь он признает материнской:

Царство шумных проспектов

и улиц бурливых

русской речи меня научило,

она -

материнскою кровью во мне [4, с. 134].

Поэзия Намжила на русском языке пришлась по душе людям разных национальностей. Ведь стихи пишутся на том языке, на котором свободно думаешь, они как бы диктуются тебе свыше. «Традиционно считается, что Нимбуев обогатил русскую поэзию восточным колоритом. Но он сделал гораздо больше - он синтезировал такой способ говорить, который одинаково осветил и русскую, и бурятскую культуру... Нимбуев обратился к русской культуре как равный, преподнеся ей в дар неамбициозное, открытое, деликатное приветствие: “Я бурят, я песчинка огромной оранжевой Азии"» [1, с. 167-168].

Конечно, большую роль в становлении личности Намжила оказал его отец, известный бурятский поэт Шираб Нимбуевич Нимбуев. Он писал на бурятском языке для детей серьезные стихи и веселые поэмы-сказки, лирические миниатюры. У него было традиционное восточное образование, которое получал в Эгитуйском дацане до 13 лет. Там он овладел старомонгольской письменностью, читал на тибетском языке буддийские книги. В советское время переростком учился в школе, закончил комвуз и начал работать учителем. Более одиннадцати лет он был переводчиком, сотрудником посольства в Монголии.

Четверо детей видели в отце близкого друга, который жил их жизнью, писал такие стихи, чтобы они были понятны и детям, и взрослым. Дети с удовольствием цитировали веселые истории из «Зархай, сын Тархая». На родине отца - урочище Маракта Еравнинского района, где в основном живут хори-буряты, прошло детство Намжила, становление его внутреннего мира и художественного сознания Намжила. Тесная связь с родиной предков чувствуется во многих его стихотворениях, имеет особенный, неповторимый след в его поэзии.

Начал писать стихи с четырех лет. Первое свое стихотворение написал на бурятском языке: «Мама моя красивая, / у нее в ушах серьги. / Папа мой красивый, / у него на глазах очки» (Мамамни гоё даа / иэхэндээ һиихэтэй, / Папамни һайхан даa / нюдэндээ шэлэтэй) (здесь и далее — из архива семьи). Первую медаль за стихи он получил во Всесоюзном лагере «Артеке». Любил все оригинальное, был инициатором семейных и школьных мероприятий. Из далекого детства пришли затем стихи, в которых проявился его задорный характер, щедрость души:

Я нынче фартовый, я нынче богатый в карманах бренчат золотые дукаты.

Пишу я друзьям: «У нас в городе осень! 
С оказией первою

милости просим!»

И в каждый конверт, как персидский царек, я щедро кладу

тополиный листок.

16 мая 1971 г.

По воспоминаниям его родных, когда они были в деревне, его большого сердца хватало на всех, во всех его, казалось бы, обыкновенных поступках почему-то чувствуется щемящая душу беззащитность. Все, кто знал Намжила, подчеркивают его незащищенность, отзывчивость и открытость всему миру. Незащищенность его натуры сквозит в его лирике, прозе, как какая-то неуловимая, только Намжилу присущая черта характера. Думается, все раны и тревоги в стихах - от этой беззащитности его души.

Он любил уходить один и сидеть на горе Обоото в позе лотоса, созерцая закат, природу. Его, наверное, успокаивала тихая радость бытия, и это подспудное буддийское отношение к жизни, где все едино, взаимосвязано и преходяще, где господствуют отрешенность от мира, покой, гармония, легло в основу его краткостиший. Возможно, японская система мышления была духовно близка бурятскому характеру. В поэзии Нимбуева влияние восточного художественноэстетического идеала обусловлено типически сходным состоянием души, присущим ему генетически.

У Намжила была феноменальная память, в школьные годы он учился одинаково хорошо по всем предметам. Когда окружающие восхищались его особым даром все запоминать, он почему-то с грустью говорил, что это отклонение от нормы. Он чувствовал свою особенность, отличие от всех, и это было тоже поводом для одиночества души. Он ничем не был обделен в жизни, но чувствовал страдающие души, как будто жил их жизнью. Когда читаешь его рассказы («Светлана», «Доржик») о девушке-калеке или одиноком мальчике, растущем без матери, постоянно ощущаешь его сочувствующее дыхание. Художник Николай Дудко точно уловил его внутреннее состояние одиночества и боли, нарисовав портрет Намжила с пылающим сердцем в руках, в этом собирательном образе раскрыв его суть:

Поэт умрет.

Анатом вскроет тело -

поэзии земную оболочку -

и вынет коченеющее сердце.

И взору изумленному предстанут

вонзившиеся в сердце глубоко

индейских стрел кремневые концы,

гарпуны костяные папуа,

обломки скифских смертоносных копий, кусочек пули дьявольской «дум-дум», осколок разорвавшейся гранаты... 
Л. С. Дампилова. «Немыслимо короткой жизни вспышка»: опыт литературной биографии Намжила Нимбуева

И миру станет ясно, почему

так мало прожил он,

и почему

прожгла насквозь стихи его простые

незримая пронзительная боль [4, с. 78].

Эта «незримая пронзительная боль», присутствующая в отношении поэта к людям, стала основным мотивом его лирики и прозы.

Будучи школьником, печатал свои стихи и заметки в газетах и журналах, так, например, в 8-м классе написал статью о своей поездке в «Артек», о кубинских ребятах, с которыми там познакомился. Переводил с бурятского языка стихи отца, сделал подстрочный перевод отцовской сказки «Зархай, сын Тархая».

После окончания средней школы Намжил работал в газете «Молодежь Бурятии», зарабатывая необходимый трудовой стаж для поступления в Литературный институт. Проработав год, Намжил поступил в Литературный институт им. Горького. В институте он приобрел друзей из разных стран, однокурсники удивлялись его разносторонним интересам. После посещений переводческих семинаров остались его переводы стихотворений и рассказов с монгольского и бурятского языков.

В этот период он увлекался поэзией Гийома Аполлинера, разными поэтическими жанрами, искал свой почерк, свой голос. Серьезно изучал теорию свободного стиха и написал курсовую работу на тему: «От чего не свободен свободный стих». Намжил сознательно выбрал свободную форму стихосложения, ибо считал, что в свободном стихе можно выразить свое «национальное лицо, душу своего народа». А восточную культуру, буддийскую философию изучал с особым интересом, великолепно знал китайскую, японскую поэзию и выбрал для размышлений краткую форму японских трехстиший. В своих краткостишиях он далек от обыденного восприятия жизни, даже случайный эпизод в его тексте приобретает особый смысл неожиданностью восприятия:

Так хорошо было в этот вечер,

Трогался переполненный трамвай.

Смеющаяся старая женщина

Подбирала на снегу

Пуговицы [4, с. 211].

В студенческие годы Намжил с другом калмыком Олегом Манджиевым написал повесть детективного жанра для подростков «Мальчишка с бантиками». Отдельно стоит упомянуть его письма родным, девушкам, они звучат как стихи, как песни души. Одно из самых характерных писем девушке Жене, живущей в городе Орске: «Здравствуй, Женя! Бумажная бомбардировка, водопад душевных излияний, прыть и одновременно терпение в поисках встреч, видимо, рождают впечатление, что я маниакально домогаюсь обратных чувств, видимо, я поспешными действиями не укладываюсь в Твои понятия об этих вещах, и нелеп, забавен, как кибернетическая кукла с запрограммированными переживаниями и синтетическими слезами. Возможно, своими выходками я многое потерял в Твоих глазах. Мои чувства, конечно, выглядят старомодно, как важный сухонький старичок в соломенной шляпе-канотье и в галошах “прощай, молодость” времен нэпа, не вызывая ни доверия, ни уважения, кроме, единственно, исследовательского любопытства. Наверное, следовало бы мне родиться двумя-тремя веками 
раньше где-нибудь в Испании, близ Барселоны. Я во многом нравственно ниже тебя, но мое отношение к тебе бескорыстно. 31 марта, 1971 г.».

Некоторые строчки из писем перешли в его рассказы, ведь его письма - тоже полет фантазии, творческий процесс. В них намечаются и сюжетные зарисовки, и неожиданные ракурсы видения мира, конечно же, его особый почерк письма. При всем его ироническом, немного юмористическом стиле изложения мыслей подспудно видится его ранимое сердце, а более всего - его стеснительная, одинокая душа ищет понимания, поддержки.

Осенью 1971 г. он много писал, печатал свои стихи, не выходя из своей комнаты, и как-то задумчиво сказал: «Наверное, я не доживу до Сагаалгана». В нем жило предчувствие скорой смерти: «Я хочу умереть легко и красиво, словно буду отбывать на ту станцию, где договорилось встретиться со мной остающееся человечество». В октябре Намжил уехал на родину, в любимую Маракту, и там остановилось его сердце, ему было 23 года. Поэт похоронен на родине предков, на земле Маракты, на тихом бурятском кладбище, на солнечной поляне.

Поистине: «немыслимо короткой жизни вспышка»... Поэту было отпущено самое большее - лет пять для творческого поиска, и он успел сделать очень много за это короткое время. Он ушел еще не понятым и не принятым в широкий писательский круг. Он не спешил, готовил свой первый сборник «Стреноженные молнии» стихотворений, много раз перебирал свои стихи, выбирал, сомневался, в его архивах сохранились варианты одного текста. Например, все знают им выбранное для сборника стихотворение о любви, где мужское начало олицетворяет Вечное небо, а женское - Синее море, и это традиционные символы для монгольской культуры:

Я опрокинусь небом,

ты разольешься морем,

мы засинеем вместе

горизонтом вдали...

Буду в тебе отражаться,

будем с тобой целоваться,

и поплывут между нами

белые корабли!»

Второй вариант производит иное впечатление, включается чувство бесконечного времени, исчезает безмятежность, уже четко ощущается, что встреча предполагается не в этом мире:

«Ты разольешься морем,

я опрокинусь небом,

на горизонте синем

встретимся на века.

Буду в тебе отражаться,

будем с тобой целоваться, поплывут между нами

лодки и облака». [4, с. 31].

Так он неторопливо подбирал каждое слово, меняя смысл текста. Он чувствовал свою неординарность, примечательно, что как-то сказал родным: «Вы еще меня не понимаете. А вот через десять лет меня оценят и поймут». 
Л. С. Дампилова. «Немыслимо короткой жизни вспышка»: опыт литературной биографии Намжила Нимбуева

Первая книга «Стреноженные молнии» вышла на газетной бумаге со скромным оформлением в 1974 г. в Бурятском книжном издательстве. Маленькая книжка имела огромный успех, молодежь была в восхищении, и известные поэты признавали дар поэта. Через год его друг Николай Кучмида в Москве дополнил сборник, и книга вышла в издательстве «Современник» с оформлением известного российского художника Михаила Ромадина. Впоследствии в своей книге «Хаммер» М. Ромадин, восхищенный творчеством Нимбуева, написал статью «Стихотворение бурятского поэта» [5, с. 198-202]. В диптихе «Поэты» Михаила Ромадина Намжил изображен в окружении Евгения Евтушенко, Осипа Мандельштама, Марины Цветаевой, Михаила Лермонтова — с великими русскими поэтами рядом, наравне.

Предисловие к московскому изданию 1975 г. написал Николай Дамдинов: «Намжил Нимбуев трепетному, нежному содержанию своей лирики нашел такую же нежную, изящную, напоминающую крылья стрекозы, форму. Несмотря на молодость, Нимбуев знал, что такое труд - упорный, целеустремленный. Талант и целеустремленность - вот два крыла, на которых поэт взлетает к вершинам» $[2$, с. 6].

И с этого периода «началось восхищение поэзией Намжила», по словам Виктора Костригина (Из архива автора - Л. Д.). Каждый, кто хоть немного знаком с Бурятией, с восточным миром, читают его легкие, немного грустные, философские, по-молодому задорные стихи. Вечные вопросы, волнующие человечество, он задавал в свои двадцать лет, и за такой короткий срок в своей поэзии как бы прожил все возрасты человека. «Звезды со страхом думают, / Что погаснут через миллион лет, / А каково людям / С их краткой, как выстрел, жизнью?» Эти его строки высечены на мемориальной гранитной доске на его доме по проспекту Победы.

Проза продолжает его поэзию, здесь та же прозрачность и философская задумчивость, характерная его почерку. Многие эпизоды из его прозы можно прочитать как отдельную лирическую миниатюру. Так, в рассказе «Одинокий осенний трамвай» открывается завершенный осенний пейзаж: «Над всем этим стояла потрескивающая звёздами осенняя ночь, невольно напоминая прозрачный сосуд с переохлажденной водой: стоит сорваться неосторожному крику - ночь мгновенно превратится в темную глыбу льда, и весь осенний пейзаж окажется внутри ледяной глыбы, будто разноцветные цветы и птицы в безделушке из литого стекла» [4].

У Намжила было особое чувство времени. Чутье мало отпущенного времени пронизывает его творчество. Если в реальной жизни судьба и время тесно взаимосвязаны, то в жизни искусства время теряет свою ежеминутную суетную силу и превращается в вечное. Герой Нимбуева — мальчик, удивленно взирающий на этот мир, чистый и хрупкий, часто наивный и беспомощный. Время бесконечно и мгновенно: он мальчик, наблюдающий за жизнью, играющий словом-яблоком только сейчас и во все времена:

Стою на планете

под деревом моей родины.

Играю словом -

румяным краснощеким яблоком -

подкидываю и ловлю его,

подкидываю и ловлю его [4, с. 72]. 
Особенно знаменательны в этом стихотворении завершающие строки: «И нет времени слезы вытереть», где отразилось обнаженное чуткое сердце Намжила, болеющего душой за весь мир. Он одинокий мечтатель со своим пристальным, откуда-то со стороны наблюдающим за этой жизнью взглядом, и это вызывает щемящее чувство незащищенности и эфемерности всего светлого. Его герой, как и Маленький принц Сент-Экзюпери, навсегда сохранивший в себе незамутненную временем непосредственность восприятия жизни, чувствует себя временным посланцем на земле: «Где невзрачный застенчивый юноша / Со слезящимися вечно глазами? / Глядит на меня / Тонкомордый, нежный олень, / и рога его запрокинуты в небо» [4, с. 17]. Олень олицетворяет его внутренний мир, образ оленя кажется естественным продолжением его души.

Семья бережно сохраняет память о Намжиле, каждый листочек, написанный его рукой, сохранен и опубликован в изданиях после его смерти дополнили маленький сборник стихотворений «Стреноженные молнии». Усилиями его сестры Любови Ширабовны не раз переиздавались его произведения, переведены на другие языки, проводятся много лет поэтические уроки в школах, училищах и вузах, международные поэтические турниры. Творческими друзьями, безмерно любящими поэзию Намжила, созданы лирические телефильмы, спектакли, балет, поэтический сад камней на его родине. В саду Намжила на памятнике из белого мрамора высечены строки его стихотворения, в речке лежит мраморная плита, на которой высечены слова: «О родина, лишь гляну на тебя — моя песня умолкает смущенно».

В его поэзии «обыкновенно человеческое органически сливается с бесчисленным количеством живущих в нем миров» (Б. Аюшеев, архив автора): «Шум овечьих отар, / Звон чугунных стремян. / Крик детей у задымленных юрт, / Звук матерчатых легких гутулов»; «Здесь старики сидят на солнцепеке, / Прошедшие перебирают дни»; «Этой ночью по тихим долинам, / Кочевали куда-то на север / Тени предков моих» $[4$, с. $20,14,12]$. В его поэзии сливаются воедино картины прошлой жизни с его настоящим и будущим. Чувствуешь «усилие остановить время, попробовать изобразить его» [5, с. 199].

В поэтических картинах Намжила ощущаешь не возвращение, не возрождение, а вечное параллельное пребывание всех времен. Редкое состояние души у Намжила: только начиная жить, он уже чувствовал свою причастность к вечности, у него была обостренная связь с ушедшим миром. Параллельно с реальным миром существует близкий духу героя виртуальный мир предков, которые «ушли, не дождавшись» его, но он чувствует их присутствие. Картину прошлой жизни он рисовал короткими, фотографически четкими штрихами, кажется, что срабатывает «прапамять», генетическое ощущение связи с истоком: «Полгода в седле мне качаться / До марев табунной отчизны. / Тоскую о ней и волнуюсь, / Как будто ребенка / Оставил в дому без присмотра» [4, с. 24].

У него была короткая жизнь, но он прожил в сомнениях и поисках длинную жизнь в своем творчестве. В разных вариантах в двадцать три года представил свое будущее, как будто желая прожить ее, хотя бы на бумаге: «Комнатушка с балконом во двор. / В ней наш скромный семейный уют, / двух зарплат экономный баланс»; «Засохший рубец между ребер / от рога бодливой коровы, / как память / мальчишеских лет, / сегодня жене показал я»; «Погладил сынишку / и вздрогнул: / как будто увидел / себя самого я / в зеркале времени». И над этими 
Л. С. Дампилова. «Немыслимо короткой жизни вспышка»: опыт литературной биографии Намжила Нимбуева

картинами жизни лейтмотивом звучала грустная нота: «И тонконогого коня / в шумящей роще тростниковой /из рук своих на склоне дня / в зеркальной глади родниковой / не напою и не спою» [4, с. 149, 190, 90, 151].

Намжил Нимбуев в поэзии - явление особенное. К нему обращаются многие творческие личности, черпая в его светлой лирике вдохновение, открывают новые горизонты для поисков. Многозначность его поэтических образов рождает новые творческие импульсы. На стихи Нимбуева каждое поколение молодых сочиняют песни, по мотивам его лирики театры ставят новые спектакли. Как признается писатель Виктор Костригин, создавший про него фильм «Любовь трубадура» 40 лет назад: «Чем дальше я ухожу в жизнь, тем сильнее ощущаю присутствие Намжила. Многолетнее общение становится более откровенным и близким, с годами стихи наполняются новым смыслом» (из архива автора. - Л. Д.). Виктор мечтал о создании улицы Намжила, где будут читать стихи все влюбленные в его поэзию. И мечта эта сбылась. Есть в Улан-Удэ небольшой переулок Намжила с граффити Зорикто Доржиева, Артема Маганова и Валентина Мокрий. В 2020 г. Елена Емельянова выиграла тендер и по рассказу Намжила «Хорэш, усь-усь!» создала художественный фильм «Под вечно синим небом». Творческая жизнь Намжила Нимбуева продолжается...

В скульптуре известного художника Даши Намдакова, которая называется «Поэт», маленький мальчик прижимается к длинной шее лошади, и в нем явно видится летучий образ Намжила. Постигая гибкие, утонченные линии скульптуры, чувствуешь совершенность строк Нимбуева: «О как безостановочно текуче и громогласно тело человечье». Даши Намдаков на международных поэтических турнирах имени Намжила Нимбуева дарит главный приз в виде скульптуры аистенка, который олицетворяет светлый мир поэзии нашего Намжила.

Отдельную книгу можно написать о стихах, посвященных Намжилу Нимбуеву, и о работах творческих коллективов по мотивам поэзии Намжила. Стихи и миниатюры на строчки из стихотворений Намжила Нимбуева присылали во время международного поэтического турнира со всей России, Монголии и Китая. После первых двух турниров издан сборник стихотворений «Песни нового дня». Короткая жизнь Поэта породила длинную песнь, которую будут петь потомки.

Литература

1. Михеева С. Тайный жар узнавания. О «сибирской» литературе и поэтической дипломатии Намжила Нимбуева // Уйти. Остаться. Жить. Москва: ЛитГОСТ, 2019. Т. II, ч. 1. С. 165-173. Текст: непосредственный.

2. Нимбуев Н. Ш. Стреноженные молнии. Стихи. Москва: Современник, 1975. 72 с. Текст: непосредственный.

3. Нимбуев Н. Ш. Проза. Улан-Удэ, 2016. Т. II. 575 с. Текст: непосредственный.

4. Нимбуев Н. Ш. Я песчинка огромной оранжевой Азии. Улан-Удэ: НоваПринт, 2018. 224 с. Текст: непосредственный.

5. Ромадин М. Хаммер. Москва: Гелеос, 2004. 373 с. Текст: непосредственный.

Статья поступила в редакцию 20.04.2021; одобрена после рецензирования 30.05.2021; принята к публикации 30.06.2021. 


\section{«INCONCEIVABLY SHORT LIFE FLASH»: EXPERIENCE OF NAMZHIL NIMBUEV'S LITERARY BIOGRAPHY}

\section{Ludmila S. Dampilova}

Dr. Sci. (Phil.), Chief Researcher, Institute for Mongolian, Buddhist and Tibetan Studies, SB RAS

6 Sakhyanovoy St., Ulan-Ude 670047, Russia

dampilova_luda@rambler.ru

The article presents a version of the literary biography of the Buryat Russian-speaking poet Namzhil Nimbuev (1948-1971). The author shows the biography stages - childhood, father's role in formation of the future poet's personality, the beginning of creativity, studies at the Gorky Literary Institute, early death - and reflects on significance of the poet's legacy for several generations of readers. According to the author, important conditions for creating the poet's biography are the origins of creativity, moments explaining the bilingualism of the Russian-speaking national poet, materials of an epistolary nature, as well as the memories of the poet's relatives and friends, critical articles and responses. The main requirement is still the reflection of the character, personality, aesthetic ideas in the work of the poet who died so early and left a grateful memory in the readers' minds.

Keywords: Namzhil Nimbuev, poetry, prose, biography, reflection of personality in creativity.

For citation

Дампилова Л.С. «Немыслимо короткой жизни вспышка»: опыт литературной биографии Намжила Нимбуева. Bulletin of Buryat State University. Philology. 2021; 2: 62-70 (In Russ.).

The article was submitted 20.04.2021; approved after reviewing 30.05.2021; accepted for publication 30.06.2021. 